\title{
Tiesisks darijjums un tā noslēgšanas brīdis zemes likumiskās (piespiedu) nomas tiesisko attiecību gadijumā
}

\author{
Arta Snipe \\ Zvērināta advokāte, Latvijas Zvērinātu advokātu kolēgiija \\ arta@snipe.lv
}

\section{Kopsavilkums}

Pēc Latvijas valsts neatkarības atjaunošanas tika sākta zemes reforma, atjaunojot bijušajiem īpašniekiem vai viṇu mantiniekiem ìpašuma tiesības uz zemi, uz kuras padomju varas gados bija uzceltas daudzdzīvokḷu dzīvojamās ēkas. Pien̦emot lēmumu zemes un ēkas īpašnieku savstarpējās tiesiskās attiecības regulēt atbilstoši nomas līguma noteikumiem, likumdevējs radīja pamatu tā saukto dalīto īpašumu pastāvēšanai. Lai arī šo piespiedu nomas tiesisko attiecību nodibināšanas pamats ir likums - normas, kas iekḷautas likumā "Par zemes reformu Latvijas Republikas pilsētās" un likumā "Par valsts un pašvaldību dzīvojamo māju privatizāciju”, - pastāv atškirīīgi viedokḷi, vai starp pusēm pastāvošās tiesiskās attiecības var klasificēt kā darījumu, tostarp kā komercdarījumu, un vai šì saistîba un no tās izrietošās prasījuma tiesības ir tādas, kas izriet no likuma vai no tiesiska darījuma.

Pētijjuma mērḳis ir, interpretējot spēkā esošās tiesību normas un judikatūras atzinas, izvērtēt dažādo tiesu praksi un dažādos juridiskajā periodikā paustos viedokḷus, lai secinātu, vai zemes piespiedu noma ir atzīstama par darījumu un vai tā ir komercdarījums gadījumos, ja vismaz viena no darïjuma pusēm ir komersants, un konstatēt šì darījuma noslēgšanas brīdi un prasījuma tiesību rašanās brīdi. Pētījumā ir gūts secinājums, ka zemes piespiedu noma nav atzīstama par tiesisku darỉjumu Civillikuma izpratnē, tādēl tā nav atzīstama par komercdarījumu Komerclikuma izpratnē. Zemes nomas līgums strīdus gadỉjumā ir atzīstams par noslēgtu ar tiesas sprieduma spēkā stāšanās brīdi, savukārt zemes īpašniekam ar šo brīdi rodas pienākums izrakstìt nodokḷa rēḳinu par zemes nomas maksu.

Atslēgvārdi: zemes piespiedu noma, zemes likumiskā noma, tiesisks darījums, darïjuma noslēgšana, komercdarijums, prasījuma tiesības. 


\section{levads}

Pēc Latvijas valsts neatkarības atjaunošanas uzsākot zemes reformu [8], bijušajiem îpašniekiem vai viṇu mantiniekiem tika atjaunotas ipašuma tiesības uz zemes īpašumiem, kas laikā no 1940. līdz 1980. gadam bija atṇemti, zemi kā nekustamo īpašumu izṇemot no civiltiesiskās aprites. Vienlaikus tika saglabātas vai piešḳirtas īpašuma tiesības uz virszemes nekustamo īpašumu - ēkām un būvēm, kas likumīgi bija uzbūvētas līdz Latvijas okupācijai vai Padomju gados, - šo būvju îpašniekiem vai tiesiskajiem valdītājiem. Tādējādi starp zemes īpašniekiem un būvju îpašniekiem tika izveidotas piespiedu tiesiskās attiecības, ko likumdevējs izvēlējās regulēt atbilstoši nomas līgumu regulējošajām tiesību normām [10]. Šādas attiecības tiek dēvētas par zemes likumisko vai piespiedu nomu [35].

Tiesību zinātnē un judikatūrā ir nostiprinājusies atziṇa, ka šìs nomas attiecības pastāv neatkarīgi no pušu gribas, tām ir piespiedu raksturs [28] un tikai nosacīta līdzība ar līgumiskām attiecībām, jo būtībā šìs attiecības ir likumiskas [26; 46] un par līgumu dēvētais fakts îstenībā nav līgums [48]. Savukārt atlīdzība nomas maksas veidā pēc juridiskās dabas pielīdzināma maksājumam par zemes īpašuma tiesību aprobežojumu [12]. Pastāvot piespiedu nomas tiesiskajām attiecībām, nav pamata runāt par lietas nodošanu lietošanā un tās pieñemšanu no otras puses, kas saskaṇā ar Civillikuma vispārējās daḷas normām nodibina nomas līgumu.

Lìdz pat 2016. gadam tiesību zinātnē un tiesu praksē ir maz analizēts saistību un prasījuma tiesību, kas izriet no zemes piespiedu nomas tiesiskajām attiecībām, rašanās pamats un nodibināšanas brīdis, kā arī tas, vai zemes nomas maksas prasijumi ir pakḷauti vispārējam civiltiesiskajam noilgumam vai speciālajam (saīsinātajam) komerctiesiskajam noilgumam. 2017. gada sākumā, kad plašsaziṇas lïdzekḷos tika aktualizēts jautājums par 10 gadus vecu zemes nomas maksas parādu piedziṇu [49; 51], savus skaidrojumus tiesību normu piemērošanā sniedza Patērētāju tiesību aizsardzības centrs [53] un Tieslietu ministrija [52]. Uz šīm publikācijām sāka atsaukties tiesas konkrētos strīdos [34; 37], kā arī juridiskajā periodikā [40; 44] tika publicēti raksti.

Pētījuma mērḳis ir izvērtēt pausto krasi atšḳirīgo argumentu pamatotību, lai noskaidrotu, vai piespiedu noma ir atzīstama par darījumu un komercdarïjumu, ja vismaz viena no darījuma pusēm ir komersants, un kad nomas līgums uzskatāms par noslēgtu. Pētỉjums ir dal̦a no plašāka pētījuma, kura otrā dal̦a veltîta prasījuma tiesību noilguma jautājumiem.

Lai sasniegtu darba mērḳi, ir pētītas tiesību normas, kas regulē zemes piespiedu nomas tiesiskās attiecības, kā arī Satversmes tiesas un Augstākās tiesas Civillietu departamenta nolēmumi. Izmantojot formālās log̣ikas metodes, ir padziḷināti analizēta atsevišku apgabaltiesas kā pēdējās instances tiesas [2,440.12] spriedumu argumentācija, lai izvērtētu tiesas veiktās subsumpcijas pareizību. 
Arta Snipe. Tiesisks darījums un tā noslēgšanas brīdis zemes

likumiskās (piespiedu) nomas tiesisko attiecību gadījumā

\section{Piespiedu noma kā darijums un komercdarijums}

Saskaṇā ar tiesību teoriju par tiesību avotiem ir atzīstami normatīvie akti un vispārējie tiesību principi (pamatavoti), kā arī judikatūra, tiesību doktrīna un normatīvo tiesību aktu izstrādes procesa materiāli (palīgavoti).

Tiesību pamatavotā - likuma "Par zemes reformu Latvijas Republikas pilsētās" [10] 4. panta piektajā daḷā - noteikts, ka zemes un ēkas ìpašnieku savstarpējās attiecības, pastāvot dalītajiem īpašumiem, ir regulējamas saskaņā ar šā likuma 12. pantu. Gadījumā, ja pastāv attiecības, kuras minētais pants neregulē, piemērojami Civillikuma [1] noteikumi. Tā, piemēram, tiesību normas imperatīvi nosaka piemērojamās materiālo tiesību normas zemes un ēkas ìpašnieku tiesisko attiecību noregulēšanai, kā arī kolīziju risinājumus, identificējot speciālo tiesību normu (to avotu jeb normatīvo aktu).

Civillikuma 1484. pantā noteikts: ja likums prasa rakstisku formu kā būtisku darījuma sastāvdaḷu, tad darỉjums pirms akta taisīšanas nav spēkā. Likuma "Par zemes reformu Latvijas Republikas pilsētās" 12. panta otrajā prim dạ̦ā un likuma "Par valsts un pašvaldību dzīvojamo māju privatizāciju" [9] 54. panta otrajā dạ̦ā, redakcijās, kas stājušās spēkā 2009. gada 1. novembrī, noteikts, ka par zemes nomas maksu un arī par tās samaksas terminịiem puses vienojas rakstveidā. Tā kā darījuma rakstveida forma kā obligāta ir noteikta likumā, pirms noformēšanas rakstveidā šis darījums nav spēkā, bet spēkā neesošs darījums nevar būt komercdarījums. Tas izriet arī no Civillikuma 1427. un 1533. panta.

Tiesību palīgavotos - tiesību zinātnē - ir pausts viedoklis, ka rakstveida līguma noslēgšana piespiedu nomas gadījumā nav nepieciešama, jo likumiskā (piespiedu) noma pastāv bez pušu gribas izteikuma un bez parakstītiem līgumiem [46, 347], jo šis ir likumiskas attiecības, kas izveidojušās uz likuma pamata [35, 12]. Minētais atkārtots arī Augstākās tiesas formulētās judikatūras tēzēs, ka tiesas spriedums, ar kuru konstatētas piespiedu nomas attiecības, aizstāj jebkāda cita akta taisīšanu; no minētā judikatūrā vairākkārtīgi ir izdarìts secinājums, ka zemes piespiedu noma nav darījums. Šīs tēzes atkārtotas Augstākās tiesas Civillietu departamenta 2016. gada 4. marta spriedumā lietā Nr. SKC-40/2016, kurā uzsvērts, ka nomas attiecībām ir piespiedu raksturs, jo tās pastāv neatkarīgi no zemes īpašnieka gribas, tādējādi uz likuma pamata pastāvošas nomas tiesiskās attiecības nevar kvalificēt kā komercdarījumus [17].

Arī lietā Nr. SKC-255/2016 Augstākā tiesa ir norādījusi: n,emot vērā faktu, ka zeme jau vēsturisku notikumu dēḷ atrodas dzīvokḷu īpašnieku lietojumā, ir apšaubāma nomas līguma slēgšanas nepieciešamība un piespiest šo līgumu noslēgt ir absurds [16]. Savukārt 2016. gada 22. novembra spriedumā lietā Nr. SKC-198/2016 Augstākā tiesa ir norādījusi, ka uz likuma pamata pastāvošās zemes nomas tiesiskās attiecības nevar kvalificēt kā darïjumu un tām nav konstatējamas komercdarījuma pazīmes [13]. 2016. gada 20. decembra spriedumā lietā Nr. SKC-349/2016 Augstākā tiesa ir uzsvērusi, ka tiesiska darījuma obligāta pazīme ir tās dalībnieku gribas izteikums. Piespiedu nomas attiecībām nav brīvprātības un pušu labprātīgas vienošanās elementa, jo tās pastāv 
neatkarīgi no zemes īpašnieka vai ēku īpašnieka gribas uz likuma pamata. Piespiedu nomas attiecībām ir tikai nosacìta līdzība ar līgumiskām attiecībām, jo būtībā šìs attiecības ir likumiskas [12].

Secināms, ka Augstākās tiesas judikatūra ir vienveidīga, - piespiedu nomas tiesiskās attiecības kā tiesiskās attiecības, kas radušās uz likuma pamata, nav uzskatāmas par darījumu, no kā izriet, ka tās nav atzīstamas arī par komercdarījumu, jo komercdarījums ir viens no tiesisko darijumu paveidiem, kā to tieši nosaka Komerclikuma 388. pants. Tas gan neliedz pusēm vienoties, ar likumu noslēgto zemes nomas līgumu grozit, noslēdzot (parakstot) rakstisku konsensuāllīgumu - tās ir pušu tiesības, bet ne pienākums, jo tas ir līgums par citu jautājumu noregulēšanu apstākḷos, kuros jau ir izveidojušās nomas attiecības [46, 347].

Secinājums, ka likumiskās attiecības nav atzīstamas par darījumu, nav apstrīdēts arī juridiskajā periodikā $[40,44]$ un virknē tiesu nolēmumu [29, 30]. Tomēr pretējs viedoklis ir izteikts atsevišķos tiesu nolēmumos, kuros secināts: ja zemes īpašnieks ir komersants, kurš zemi ir ieguvis komercdarījuma rezultātā, zemes un ēkas īpašnieku tiesiskās attiecỉbas pèc bütìbas ir komercdarījums.

N̦emot vērā būtiski atšḳirīgo tiesu praksi, ir nepieciešams plašāk aplūkot tiesu veiktā deduktīvā slēdziena (juridiskā siloǵisma) pareizumu (validity) un neapstrīdamību (soundness). Šim nolūkam analīzei ir izmantota vairākos Rīgas apgabaltiesas kā apelācijas un pēdējās instances tiesas $\left[2,30 .^{3}\right.$ nodaḷa, $54 .{ }^{1}$ nodaḷa, $440 .{ }^{12}$ pants $]$ spriedumos ietvertā gandrīz identiskā argumentācija, atseviški rekonstruējot katru apgabaltiesas izdarìto deduktīvo slēdzienu, lai izvērtētu tā pareizumu un neapstrīdamību no formālās logiikas viedokḷa. Analizētie spriedumi satur vairākas premisas, tostarp lielās premisas jeb virsteikumus (tiesiskie apstākḷi jeb tiesību normas) un mazās premisas jeb apakšteikumus (faktiskie apstākḷi) [41, 477], kā arī secinājumus, kas tiek izdarīti no šīm premisām. Premisas, noklusētās premisas [43, 103-104] un slēdzieni tiks izkārtoti logikas ḳēdēs, lai tos analizētu un konstatētu, vai visos posmos izdarītie slēdzieni ir pareizi un neapstrīdami, t. i., vai tiesa subsumpciju ir veikusi pareizi. Tiesiskās sekas (pareizs secinājums) var iestāties tikai gadījumā, ja virsteikumā (lielajā premisā) un apakšteikumā (mazajā premisā) ir vienots starptermins (ir konstatējams, ka sakrìt normas tiesiskais sastāvs un lietas apstākḷi) [41, 477].

Argumentējot par labu tam, ka zemes piespiedu noma ir darījums un tātad arī komercdarījums, 11.10.2017. spriedumā lietā Nr. C30454917 [32] tiesa slēdzienu pamatojusi ar šādām premisām:

(1) Zemes īpašnieks ir ierakstits komercreǵistrā - mazā premisa;

(2) Komersants ir komercreǵistrā ierakstìta fiziskā persona (individuālais komersants) vai komercsabiedrība (personālsabiedrība un kapitālsabiedrība) - lielā premisa, Komerclikuma 1. panta pirmā dal̦a;

(3) Zemes ippašnieks ir komersants - secinājums no (1) un (2). 
Arta Snipe. Tiesisks darījums un tā noslēgšanas brīdis zemes

likumiskās (piespiedu) nomas tiesisko attiecību gadījumā

Šis ir pareizs un neapstrīdams deduktīvs slēdziens. Arī nākamo tiesas slēdzienu var rekonstruēt deduktīvā slēdziena pamatformā:

(3) Zemes īpašnieks ir komersants - secinājums no (1) un (2);

(4) Komercdarbība ir atklāta saimnieciskā darbība, kuru savā vārdā peḷnas gūšanai veic komersants - lielā premisa, Komerclikuma 1. panta otrā daļa;

(5) Komercdarījums ir komersanta tiesiskais darījums, kas ir saistīts ar komercdarbību lielā premisa, Komerclikuma 388. pants;

(6) Zemes gabalu zemes īpašnieks ieguvis pirkuma rezultātā, lai izmantotu komercdarbībā - mazā premisa, kuras patiesumu puses neapstrīd;

(7) Zemes īpašumu zemes īpašnieks (komersants) ieguvis komercdarījuma rezultātā secinājums no (3), (4), (5) un (6).

Arī šis siloğisms ir atzīstams par pareizu un neapstrīdamu deduktīvu slēdzienu $[43,94]$. Visas tā premisas ir vai nu patiesas, vai arī tādas, par kuru patiesumu puses ir vienojušās [43, 47].

Kaut gan nākamie tiesas secinājumi ir balstīti uz pien,ēmumiem, tie ir loğiski pareizi un neapstrīdami, jo pieṇēmumus neviena no pusēm nav apstrīdējusi:

(8) Zemes īpašnieks, iegādājoties zemesgabalu, ir zinājis par dalīta īpašuma pastāvēšanu - mazā premisa, kuras patiesumu puses neapstrīd;

(9) Zemes īpašnieks, iegādājoties zemesgabalu, apzinājās, ka īpašums nevar tikt izmantots paša vajadzībām - secinājums no (8);

(10) Zemes gabala mērḳis bija izmantot to komercdarbībai - iznomāšanai un peḷnas gūšanai no nomas maksas - secinājums no (9);

(11) Zemes īpašnieka darbības ar zemes gabalu, tostarp iznomāšana, tiek veikta komercdarbības ietvaros - secinājums no (9).

Sarežgìtāk ir ar nākamo tiesas slēdzienu:

(11) Zemes īpašnieka darbības ar zemes gabalu, tostarp iznomāšana, tiek veikta komercdarbības ietvaros - mazā premisa;

(12) Zemes īpašnieks īpašuma tiesības uz zemes gabalu ieguvis komercdarījuma rezultātā - mazā premisa;

(13) Starp zemes īpašnieku un dzīvokḷu ỉpašnieku pastāvošās tiesiskās attiecības, kuru ietvaros komercsabiedrība iznomā zemes īpašumu un pieprasa zemes nomas maksu, pēc būtības ir komercdarījums - secinājums no (11) un (12).

Kaut gan šis slēdziens atbilst arī Tieslietu ministrijas publicētajam viedoklim tiesību normu piemērošanas jautājumos [52], tomēr tas neiztur formālās logikas kritiku. Secinājums tieši neizriet no premisām, jo pirmā premisa satur apgalvojumu attiecībā uz zemes nomu kā darījumu, savukārt otrā - attiecībā uz darījumu, ar kuru zemes gabals ir iegūts īpašumā. Proti, abām premisām trūkst vienota starptermina, lai varētu izdarìt pareizu log̣isku secinājumu. Citiem vārdiem sakot, viena slēdziena premisa ietver 
apgalvojumu par darījumu ar konkrētu darījuma priekšmetu un darījuma pusēm. Ja zemes īpašnieks ir ieguvis zemi darījuma ceḷā (pat ja uz komercdarījuma pamata), šis darījums un no tā izrietošās saistības un prasījuma tiesības jau ir izpildītas - darījums ir beidzies ar izpildījumu, atsavinātajam saṇemot, piemēram, pirkuma maksu, savukārt ieguvējam - nostiprinot īpašuma tiesības zemesgrāmatā.

Slēdziena secinājums ietver cita, nošḳirta darījuma juridisko kvalifikāciju. Zemes īpašuma tiesību iegūšanas apstākḷiem un pamatam nav tiešas ietekmes uz tiesisko attiecỉbu saturu, kas veidojas starp zemes un ēkas īpašnieku, jo šīs ir divas noškirtas un savstarpēji nesaistītas tiesiskās attiecības. Zemes īpašuma iegūšanas veids (piemēram, atgūstot vai atjaunojot īpašuma tiesības, mantošanas vai legāta ceḷā, uz tiesas lēmuma vai likuma pamata, uzṇēmuma vai komersanta reorganizācijas ceḷā, ierakstot fizisku personu kā individuālu komersantu komercreǵistrā vai uz tiesiska darïjuma pamata), nevar ietekmēt turpmākās rīcības ar šo īpašumu juridisko dabu un kvalifikāciju.

Zemes īpašnieka tiesības rīkoties ar īpašumu un izmantot to komercdarbībā, tostarp prasit nomas maksu, neizriet no darïjuma (vai tiesas nolēmuma), ar kuru komersants ir ieguvis īpašuma tiesības, bet gan no lietu tiesības - absolūtajām ìpašuma tiesībām uz zemes gabalu. Tādēḷ šis deduktīvais slēdziens nav pareizs (not valid). Tāpat ir iespējama situācija, ka komercdarījuma rezultātā iegūta zeme tiek lietota saimnieciskās darbības vai pat komercdarbības ietvaros, kaut gan komercdarỉjums nav slēgts, kas atkārtoti apliecina deduktīvā slēdziena nepareizību. Tādēl var secināt, ka vismaz konkrētajā (un identiski motivētajos) spriedumā tiesa nav spējusi atbilstoši log̣ikas prasībām argumentēt interpretācijas pareizību.

Lai arī tekstā tas nav expresis verbis norādīts, no sprieduma kopumā var rekonstruēt vēl vienu tiesas slēdzienu:

(14) Zemes piespiedu noma ir darījums - slēptā premisa;

(15) Komercdarījums ir viens no tiesisko darījumu veidiem - lielā premisa;

(16) Zemes piespiedu noma ir komercdarījums - secinājums no (14) un (15).

Šajā slēdzienā pirmās, slēptās, premisas patiesums ir apstrīdams - iepriekš aprakstītajā Augstākās tiesas judikatūrā ir pausts atšḳirīgs viedoklis, tādēḷ šì premisa nevar būt derīgs pamats slēdzienam. Deduktīvais slēdziens, kura secinājums ir, ka zemes piespiedu noma ir darījums, tiesu praksē nav atrodams, tas tiek pieñemts kā patiesa slēptā premisa (prezumpcija), uz kuras ir pamatots nolēmums. Tomēr, tā kā šì premisa pirmškietami nonāk pretrunā CL 1427. pantam un Augstākās tiesas atziṇām, tā nevar tikt atzìta par pirmškietami patiesu, kas liedz ar to pamatot neapstrīdamu slēdzienu. Kā norādīts tiesību teorijā, juridiskajā silog̣ismā parasti nav uzreiz redzams, vai normas tiesiskais sastāvs sakrīt ar konkrētajiem faktiskajiem apstākḷiem un vai līdz ar to pastāv identisks starptermins, jo tiesību normas pazīmes lielākoties ir abstraktas un to saturs vispirms ir jānoskaidro [41, 478]. Aprakstītajā piemērā tiesa šo tiesību teorijas prasību nav izpildījusi. 
Premisām trūkst arī vienota starptermina - no tā, ka gan zemes noma, gan komercdarījums ir viens no darījumu veidiem, nav iespējams izdarìt pareizu secinājumu, ka zemes noma ir komercdarījums. Atbilstoši formālajai logiikai tas, ka A ir dala no B un arī $C$ ir dalı no no nenozīmē, ka $A=C$, tomēr tiesas spiedums ir pamatots tieši ar šādu slēdziena konstrukciju, kas ir acīmredzami nepareiza. Protams, ir iespējama situācija, ka $\mathrm{A}=\mathrm{C}$, tomēr tā būs uzskatāma par sagadīšanos, un tas nav uzskatāms par pareizu (valid) slēdzienu. Citiem vārdiem sakot, (14) premisu iespējams pārformulēt kā "zemes piespiedu noma ir viens no darījumu veidiem", bet (15) premisu iespējams pārformulēt kā "komercdarïjums ir viens no darījumu veidiem", kas abi kopā nedod pamatu secinājumam, ka zemes piespiedu noma ir komercdarijums.

Secinājums, ka zemes noma ir komercdarījums, tiek izdarīts arī paralēla deduktīiā slēdziena ietvaros:

(17) Iznomātājs ir komersants;

(18) Visi komersanta slēgtie darījumi ir komercdarbïba;

(19) Zemes iznomāšana ir komercdarījums - secinājums no (17) un (18).

Slēdziens ir pareizs tikai tad, ja nav iespējams, ka abas premisas ir pareizas, bet secinājums - nepareizs [43, 91]. Apskatāmais slēdziens nav atzīstams par pareizu, jo ir iespējama situācija, kurā iznomātājs ir komersants, bet tā slēgtais darījums nav atzīstams par komercdarījumu. Tā komersanta darījumi publisko tiesību jomā, piemēram, pārvaldes funkciju delegéjuma līgumi, pat ja ietver rīcību ar komercdarījuma rezultātā iegūto zemi, nav komercdarījumi (lai arī ir komercdarbība, jo komercdarbība ir plašāks jēdziens nekā komercdarījums) [31], komercdarïjumi nav arī tiesiskie darïjumi, kas slēgti, pildot likuma prasības, vai kurus likumdevējs ir strikti norādījis kā civiltiesiskus darījumus, kas nav komercdarïjumi, piemēram, èkas apsaimniekošanas līgumi [33]. No konkrētā slēdziena analīzes viedokḷa būtiski ir tas, kas šajā slēdzienā netiek vērtēts saistības rašanās pamats secinājums neizriet no premisām, jo zemes iznomāšana var notikt gan uz likuma pamata, gan slēdzot darījumu. Tātad slēdziens nav pareizs, jo tiek izdarīts vispārināts pienēemums un arī šajā slēdzienā ir pielautas formālās log̣ikas kḷūdas.

Tādẹl var secināt, ka nav iespējams ar pareiziem un neapstrīdamiem deduktīviem slēdzieniem pamatot secinājumu, ka zemes piespiedu noma ir atzīstama par komercdarïjumu.

No otras puses, rekonstruējot Augstākās tiesas judikatūrā ietverto secinājumu par to, ka zemes piespiedu noma nav komercdarījums, var konstatēt, ka tas izriet no līdzīga deduktīvā slēdziena ar atšḳirīgu (1) premisu:

(1) Zemes piespiedu noma nav darïjums;

(2) Komercdarïjums ir viens no darījuma veidiem;

(3) Zemes piespiedu noma nav komercdarījums - secinājums no (1) un (2). 
Arta Snipe. Tiesisks darījums un tā noslēgšanas brīdis zemes

likumiskās (piespiedu) nomas tiesisko attiecību gadijumā

Atškirīibā no aplūkotā apgabaltiesas sprieduma Augstākā tiesa pamato arī (1) premisas patiesumu, turklāt tā ir tiešs secinājums no divām citām premisām:

(4) Pie tiesiska darījuma būtības pieder tā taisītāja gribas izteikums, bet divpusējā vai vairākpusējā darījumā vajadzīgs visu tā dalībnieku saskanīgs gribas izteikums - lielā premisa, CL 1427. pants;

(5) Zemes piespiedu noma pastāv bez pušu gribas - mazā premisa;

(6) Zemes piespiedu noma nav darījums - secinājums no (4) un (5).

Aplūkotais deduktīvais slēdziens ir atzīstams gan par pareizu, gan neapstrīdamu, jo nav iespējams noslēgt darījumu, neizsakot gribu (CL 1404. pants), tātad pirmā deduktīvā slēdziena (1) premisa ir atzīstama par pareizu, arī (2) premisa ir tāda, par kuru pastāv tiesību normu piemērotāju vienprātība, no kā izriet arī pirmā deduktīvā slēdziena pareizums un neapstrīdamība.

Tādēḷ pēc formālās log̣ikas likumiem var secināt, ka pareizi juridiskie silogismi ir ietverti Augstākās tiesas spriedumos lietās Nr. SKC-40/2016, Nr. SKC-349/2016, bet ne analizētajā Rīgas apgabaltiesas spriedumā un tam līdzīgi motivētajos, proti, likumiskās zemes piespiedu nomas tiesiskās attiecības nav atzīstamas par darijumu, tātad tās nav atzīstamas par komercdarījumu neatkarīgi no tā, vai viena vai abas nomas attiecību puses ir komersanti un nomas attiecības ir saistìtas ar nomnieka vai iznomātāja komercdarbību [7].

\section{Darijuma noslēgšanas brīdis}

Piespiedu nomas tiesiskās attiecības var pastāvēt gan uz likuma pamata, gan arī pusēm noslēdzot rakstveida nomas līgumu, piemēram, ievērojot likumā imperatīvi noteiktos ierobežojumus attiecībā uz funkcionāli nepieciešamo zemes gabala platību, vienojoties par citiem noteikumiem - papildu platības nomu, nomas maksas apmēru un tās samaksas termiṇiem. Likuma "Par zemes reformu Latvijas Republikas pilsētās" 12. panta otrajā prim dạ̦ā un likuma "Par valsts un pašvaldỉbu dzīvojamo māju privatizāciju” 54. panta otrajā dạ̦ā no 2009. gada 1. novembra rakstveida līguma forma ir noteikta kā obligāta tā sastāvdaḷa, tātad līdz rakstveida līguma parakstīšanai jebkuras citas konsensuālas vienošanās ir atzīstamas par spēkā neesošām $(1,1475)$.

Ja puses rakstveida līgumu nav noslēgušas, to savstarpējās tiesiskās attiecības regulē likums, attiecīgi - likuma "Par zemes reformu Latvijas Republikas pilsētās" 12. pants, likuma "Par valsts un pašvaldỉbu dzīvojamo māju privatizāciju" 54. pants, kā arī 50. panta pirmā dạ̦a un Dzīvojamo māju pārvaldīšanas likuma 6. panta otrās daḷas 4. punkts un

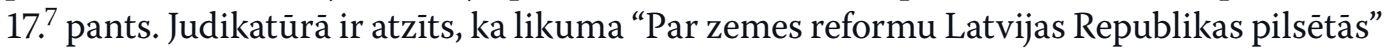
12. pants ir tulkojams šādi:

“[..] zemes un ēkas īpašniekam dots uzdevums savstarpēji saistities, noslēdzot līgumu atbilstoši brīvprātības principam, savukārt, ja vienošanās par līguma noteikumiem nenotiek - strīda gadijjumā - nomas tiesisko attiecỉbu konstatāciju (atzīšanu) veic tiesa, nodibinot ar tiesas spriedumu nomas līguma būtiskās sastāvdaḷas (Civillikuma 2124. pants)" [20]. 
Arta Snipe. Tiesisks darījums un tā noslēgšanas brīdis zemes

likumiskās (piespiedu) nomas tiesisko attiecību gadijumā

Tātad, lai arī zemes īpašniekam ir ar likumu noteiktas tiesības prasìt un saṇemt zemes nomas maksu, šā prasījuma priekšnoteikums ir nomas tiesisko attiecību konstatācija (nodibināšana).

Vēršoties ar prasību tiesā, zemes nomas līgums būs atzīstams par galīgi noslēgtu tikai pēc sprieduma spēkā stāšanās, jo tikai tad ir nodibinātas darỉjuma būtiskās sastāvdaḷas (CL 1533. pants) [18]. Ši judikatūrā nostiprinātā atziṇa saskan arī ar Valsts ieṇēmumu dienesta sniegto Pievienotās vērtïbas nodokḷa likuma 127. panta pirmās daḷas un 131. panta pirmās daḷas skaidrojumu [54] - ja ir konstatējams strīds, "darījums būs uzskatāms par noslēgtu brīdī, kad tiesas nolēmums stāsies spēkā. Tādējādi zemes īpašniekam ir pienākums izrakstìt nodokḷa rēḳinu 15 dienu laikā no sprieduma spēkā stāšanās dienas un veikt PVN samaksu valsts budžetā" [29]. Ja ar tiesas spriedumu nomas līgums tiek noslēgts (ja prasītājs ir iekḷāvis šādu uz nākotni vērstu prasījumu un tiesa to ir apmierinājusi), turpmāk uz šì sprieduma, līdzịgi kā uz jebkura līguma, pamata zemes īpašniekam ir pienākums par zemes nomniekiem sniegto zemes nomas pakalpojumu izrakstīt pievienotās vērtības nodokḷa rēḳinu ne retāk kā reizi sešos mēnešos [54]. Tādēḷ tiesību normās un tiesu praksē, kurā apskatīts šis jautājums, kā arī judikatūrā ir vienots viedoklis, ka par darījuma brīdi un pat pakalpojuma sniegšanas brīdi nodokḷu likumdošanas izpratnē ir atzīstams sprieduma spēkā stāšanās brīdis $[26 ; 15 ; 20]$.

Pēc daudzdzīvokḷ èkas privatizācijas uzsākšanas èkas un zemes īpašnieku savstarpējās tiesiskās attiecības regulē likuma "Par valsts un pašvaldību dzīvojamo māju privatizāciju" 54. pants, kā arī 50. panta pirmās daḷas 3. punkts [45]. Šā likuma normas reglamentē dzīvokḷu īpašnieku, pārvaldnieka un zemes īpašnieka savstarpējās tiesiskās attiecības līdz brīdim, kad dzīvojamās mājas īpašnieki pārṇem dzīvojamās mājas pārvaldīšanas tiesības no publiskās personas, kura ēku ir privatizējusi; turpmāk šīm attiecībām ir piemērojamas tikai Dzīvojamo māju pārvaldǐšanas likuma normas [30]. Likuma "Par valsts un pašvaldību dzīvojamo māju privatizāciju" 54. pantā, kā arī 50. panta pirmās daḷas 3. punktā noteikts, ka privatizētā objekta īpašniekam ir pienākums slēgt zemes nomas līgumu vai pilnvarot dzīvojamās mājas pārvaldītāju un apsaimniekotāju slēgt zemes nomas līgumu ar zemes gabala, uz kura atrodas privatizētais objekts, īpašnieku. Zemes īpašnieka pienākums noslēgt nomas līgumu ar privatizētā objekta îpašnieku noteikts likuma 54. panta pirmajā dal̦ā, savukārt panta ceturtajā dal̦ā precizēts: ja atbilstoši šā likuma 50. panta pirmās dalas 3. punkta prasībām zemes nomas līgumi ar zemes gabala ipašnieku nav noslēgti, zemes gabala īpašniekam ir tiesības prasỉbu par zemes nomas līguma noslēgšanu tiesā vērst pret personu, kurai nodotas attiecīgās dzīvojamās mājas pārvaldīšanas un apsaimniekošanas tiesības (pārvaldnieku).

Tiesības un pienākumi, kas izriet no nomas tiesiskajām attiecībām starp zemes īpašnieku un pārvaldnieku, vienlīdz attiecas arī uz dzīvojamās mājas dzīvokḷu ỉpašniekiem un ir tiem saistoši, jo tieši viṇi ir zemes nomas tiesisko attiecību subjekti [14; 50]. Lai arī likuma "Par valsts un pašvaldību dzīvojamo māju privatizāciju" 54. panta ceturtajā dạ̣a paredzētas prasītāja izvēles tiesības ēkas privatizācijas procesa gaitā, t. i., izvēlēties celt prasību pret katru dzīvokḷa ỉpašnieku vai celt vienu prasību pret ēkas pārvaldnieku, 
kuram attiecīgi ir regresa prasības tiesības pret ēkas dzīvokḷu ìpašniekiem [11], spriedums, ar kuru būs nodibinātas nomas attiecības (noslēgts darījums), būs saistošs visiem dzīvokḷu īpašniekiem. Starp pusēm pastāvošās attiecības ir likumiskas, un spriedums ir nepieciešams, lai to būtiskās sastāvdaḷas nostiprinātu un ietērptu rakstveida aktā [15]. Ar sprieduma spēkā stāšanās brīdi būs konstatējamas visas darījuma būtiskās sastāvdaļas un darījums uzskatāms par galīgi noslēgtu, kas radīs zemes īpašniekam prasỉjuma tiesības par šì darījuma izpildi - tiesības prasìt zemes nomas maksas samaksu no ēkas pārvaldnieka, ja tiesības norēḳināties ar pakalpojumu sniedzējiem ēkas dzīvokḷu īpašnieki nodevuši pārvaldniekam $\left[3,17{ }^{2}, 17.4\right]$, vai no atseviškiem dzīvokḷu ipašniekiem [3, pārejas noteikumu 17.].

2014. gada 1. oktobrī spēkā stājās grozījumi likuma "Par valsts un pašvaldību dzīvojamo māju privatizāciju" 54. panta pirmajā dal̦ā, kas kopsakarā ar Satversmes tiesas spriedumā lietā Nr. 2011-01-01 lemto [36] radijja juridisku pamatu prasību celšanai pret atsevišķiem dzīvokḷu īpašniekiem par zemes nomas maksas piedziņu. Proti, līdz 2014. gada 1. oktobrim atbilstoši Satversmes tiesas lemtajam un judikatūrai prasijums par zemes nomas līguma noslēgšanu bija tāds, kas jāizvirza visiem zemes kopīpašniekiem, ja tādi ir, pret visiem dzīvokḷu īpašniekiem kā ēkas kopīpašniekiem, un atbilstoši CL 1068. pantam tiesai nebija tiesību noteikt nomājamo platību zemes îpašnieka individuālā strīdā ar vienu dzīvokḷu īpašnieku. Tiesa pieturējās tiesību doktrīnā [42, 64] paustajam ieskatam, ka domājamā daḷa ir bezḳermeniska lieta, to nevar iznomāt, jo lietot var kādas lietas reālu dalı vai visu lietu kopumā, to tulkojot tādējādi, ka Civillikuma 1068. pants liedz celt prasību par zemes nomas līguma noslēgšanu kopipašniekam vai pret kopīpašnieku, lietā nepieaicinot visus kopīpašniekus [27].

Ar minētajiem grozījumiem likuma "Par valsts un pašvaldību dzīvojamo māju privatizāciju" 54. pantā [5] likumdevējs expresis verbis likumā deva norādes par abām nomas līguma būtiskajām sastāvdaḷām: ja cena likumā bija noteikta jau kopš 2009. gada 1. novembra, tad ar 2014. gada 1. oktobri likums deva imperatīvu norādi uz nomājamo platību - ar administratīvo aktu, pašvaldỉbas domes vai tās pilnvarota institūcijas, vai valsts akciju sabiedrība "Privatizācijas aǵentūra" noteikto dzīvojamai mājai funkcionāli nepieciešamo zemes gabalu. Tādēl, sākot ar 2014. gada 1. oktobri, zemes īpašniekam vairs nebija nepieciešama formālā zemes nomas tiesisko attiecību konstatācijas prasība - līguma būtiskās sastāvdaḷas attiecībā uz privatizācijai nodotām dzīvojamām ēkām bija noteiktas likumā un administratīvajā aktā [38].

Arī laika posmā no 2014. gada 1. oktobra līdz 2017. gada vasarai, kad abas darījuma būtiskās sastāvdaḷas bija noteiktas, situācija nebija viennozīmīga. Nomas maksa likumā bija konkrēti noteikta vien attiecībā uz èkām, kurām nav pabeigts privatizācijas process, - Dzīvojamo māju pārvaldī̌̌anas likumā nebija un nav noteikts nomas maksas apmērs. Tas, ka nomas maksa nosakāma 6 \% no zemes gabala kadastrālās vērtības gadā, bija spēkā tikai līdz brīdim, kad stājās spēkā 2017. gada jūnijā pieṇemtie grozìjumi likuma "Par valsts un pašvaldību dzìvojamo māju privatizāciju" 54. panta otrajā daḷā [4] un likuma "Par zemes reformu Latvijas Republikas pilsētās" 12. panta otrajā prim daḷā [6]. 
Tomēr, lai konstatētu, ka saistības dzīvokḷa un zemes īpašnieka starpā nodibinājušas ne vairs uz darījuma, bet likuma pamata, ir jāpiemēro kritērijs - vai bez vienas vai abu pušu darbībām, no likuma vien, ir noskaidrojams saistības saturs [47, 17]. Strīds ir iespējams par funkcionāli nepieciešamā zemes gabala platību un konfigurāciju, ja zemes gabals nav noteikts, ēku nododot privatizācijā, kas ir faktiskā realitāte virknē īpašumu. Strīds iespējams arī par zemes vienības, ja tāda izveidota, kadastrālās vērtības aprēḳinu un pat par nomas maksas apmēru [39]. Strīdi iespējami arī par pievienotās vērtības nodokḷa piemērošanu [22, 23, 24].

Arī Augstākās tiesas Civillietu departaments ir apstiprinājis judikatūras tēzi, ka jautājumos par piespiedu nomu tiesai jāizšḳir strīds par līguma būtiskām sastāvdaḷām (Civillikuma 1533. pants), nevis par nomas tiesisko attiecību atzī̌̌anu. Tomēr, ja puses nevar panākt vienošanos pat par blakus noteikumiem, kas nav atzīstami par būtiskām darījuma sastāvdalāām, tad bez vienošanās par blakus noteikumiem līgums nav atzīstams par noslēgtu, kā to nosaka Civillikuma 1534. pants [25]. Tādēl atbilstoši CL 1533. pantam par galīgi nodibinātu nomas līguma saturu un būtiskām sastāvdaḷām, tostarp parāda apmēru un tā samaksas terminu, var runāt vien pēc sprieduma spēkā stāšanās [44].

\section{Secinājumi}

1. Zemes piespiedu noma nav atzīstama par tiesisku darījumu Civillikuma izpratnē un nav arī atzīstama par komercdarījumu Komerclikuma izpratnē.

2. Darījums (pretēji likumiskai saistībai) ir uzskatāms par noslēgtu tikai brīdī, kad puses ir vienojušās par nomas līguma būtiskajām sastāvdaḷām - platību un cenu. Gadījumā, ja labprātīga vienošanās nepastāv, darījuma aktu aizstāj tiesas nolēmums. Par darījuma noslēgšanas brīdi atzīstams tiesas sprieduma spēkā stāšanās brīdis. No šīs dienas arī rodas zemes īpašnieka pienākums izrakstīt nodokḷa rēḳinu par zemes nomas maksu.

3. Nav tiesiskas nozīmes tam, uz kāda pamata zemes ipašnieks ir ieguvis īpašuma tiesības uz zemes gabalu, jo šis darïjums vai administratīvais akts ir izpildìts ar brīdi, kad ieguvēja īpašuma tiesības tika nostiprinātas zemesgrāmatā. Zemes ìpašnieka tiesības prasìt nomas maksu izriet no lietu tiesības - ipašuma tiesībām uz zemes gabalu. 
Arta Snipe. Tiesisks darījums un tā noslēgšanas brīdis zemes

likumiskās (piespiedu) nomas tiesisko attiecību gadijumā

\section{Compulsory Land Lease as Transaction and Time of Conclusion of the Transaction}

\section{Abstract}

After the restoration of the independence of the Republic of Latvia, within the framework of the initiated land reform, the legislator restored property rights of the former owners or their heirs to the land on which apartment houses were built during the Soviet times, thus creating the basis for the so-called shared property. Legislator made the decision to regulate the relationship between the land owners and building owners according to the terms and conditions of the lease agreement. Although the basis for establishing the legal relationship of compulsory land lease is the law - the norms included in the law "On Land Reform in the Cities of the Republic of Latvia" and the law "On Privatisation of State and Local Government Residential Houses", there are different opinions as to whether the legal relations between the parties can be classified as a transaction, or as a commercial transaction, and, consequently, whether the claim arising from this obligation is arising from the law or arising from a transaction.

The aim of the research is to assess the different case laws and the opinions expressed in various legal periodicals by interpreting the applicable legal norms and the judicature, in order to conclude whether the compulsory land lease should be deemed as a transaction and whether it should be deemed as a commercial transaction in case where at least one of the transaction parties is a merchant, and to establish the time of the transaction and the time when the right to claim emerges. During the research, the conclusion was made that the compulsory land lease should not be deemed as a transaction within the meaning of the Civil Law and, consequently, it should not be deemed as a commercial transaction within the meaning of the Commercial Law. In case of a dispute, the land lease agreement should be deemed as concluded at the time when the court judgement enters into force, and the landowner's obligation to issue a tax invoice for land lease fee also emerges simultaneously.

Keywords: compulsory land lease, transaction, legal transaction, entering into transaction, commercial transaction, right to claim, claim.

\section{Izmantotie avoti un literatūra}

\section{Tiesību akti}

1. Civillikums. Ceturtā daḷa. Saistību tiesības: likums. Pieṇemts 28.01.1937. Spēkā no 01.03.1993. Valdìbas Vēstnesis. 46, 26.02.1937.

2. Civilprocesa likums: likums. Pienemts 14.10.1998. Spēkā no 01.03.1999. Latvijas Vēstnesis. 326/330 (1387/1391), Zinotōajs. 23.

3. Dzīvojamo māju pārvaldīšanas likums: likums. Pieñemts 04.06.2009. Spēkā no 01.01.2010. Latvijas Vēstnesis. 96 (4082) 19.06.2009., Ziṇotājs. 14. 23.07.2009. 
Arta Snipe. Tiesisks darījums un tā noslēgšanas brīdis zemes

likumiskās (piespiedu) nomas tiesisko attiecību gadījumā

4. Grozījumi likumā "Par valsts un pašvaldību dzīvojamo māju privatizāciju”: Saeimas likums. Pieṇemts 01.06.2017. Spēkā no 27.06.2017. Latvijas Vēstnesis. 117 (5944), 13.06.2017.

5. Grozījumi likumā "Par valsts un pašvaldību dzīvojamo māju privatizāciju”: Saeimas likums. Pieñemts 19.06.2014. Spēkā no 01.10.2014. Latvijas Vēstnesis. 131 (5191), 08.07.2014.

6. Grozījumi likumā "Par zemes reformu Latvijas Republikas pilsētās": Saeimas likums. Pieṇemts 22.06.2017. Spēkā no 13.07.2017. Latvijas Vēstnesis. 128 (5955), 29.06.2017.

7. Komerclikums: likums. Pieṇemts: 13.04.2000. Spēkā no 01.01.2002. Latvijas Vēstnesis. 158/160 (2069/2071), 04.05.2000., Ziṇotājs. 11, 01.06.2000.

8. Par valsts īpašumu un tā konversijas pamatprincipiem: Latvijas Republikas Augstākās Padomes lēmums. Pieṇemts 20.03.1991. Spēkā no 20.03.1991.Ziṇotājs. 19/20, 23.05.1991.,Diena. 69, 11.04.1991.

9. Par valsts un pašvaldību dzīvojamo māju privatizāciju: Saeimas likums. Pieṇemts 21.06.1995. Spēkā no 25.07.1995. Vēstnesis. 103, 11.07.1995. Ziñotājs. 16, 24.08.1995.

10. Par zemes reformu Latvijas Republikas pilsētās: Augstākās Padomes likums. Pieṇemts 20.11.1991. Spēkā no 20.11.1991. Ziṇotājs. 49/50, 19.12.1991., Diena. 242, 13.12.1991.

\section{Tiesu prakse}

11. Augstākās tiesas Civillietu departamenta 2016. gada 20. aprīḷ spriedums lietā Nr. SKC-5/2016 (C29859011).

12. Augstākās tiesas Civillietu departamenta 2016. gada 20. decembra spriedums lietā Nr. SKC-349/2016 (C15248612).

13. Augstākās tiesas Civillietu departamenta 2016. gada 22. novembra spriedums lietā Nr. SKC-198/2016 (C27197711).

14. Augstākās tiesas Civillietu departamenta 2016. gada 22. novembra spriedums lietā Nr. SKC-226/2016 (C30458513).

15. Augstākās tiesas Civillietu departamenta 2016. gada 26. oktobra spriedums lietā Nr. SKC-336/2016 (C39057712).

16. Augstākās tiesas Civillietu departamenta 2016. gada 3. novembra spriedums lietā Nr. SKC-255/2016 (C17116307).

17. Augstākās tiesas Civillietu departamenta 2016. gada 4. marta spriedums lietā Nr. SKC-40/2016 (C27197411).

18. Augstākās tiesas Civillietu departamenta 2017. gada 30. jūnija spriedums lietā Nr. SKC-244/2017 (C27128613).

19. Augstākās tiesas Civillietu departamenta 2017. gada 31. janvāra spriedums lietā Nr. SKC-11/2017 (C37068613).

20. Augstākās tiesas Civillietu departamenta 2017. gada 6. novembra spriedums lietā Nr. SKC-338/2017 (C30578513). ECLI:LV:AT:2017:1106.C30578513.1.S.

21. Augstākās tiesas Civillietu departamenta 2017. gada 8. decembra spriedums lietā Nr. SKC-305/2017 (C39094314) ECLI:LV:AT:2017:1208.C39094314.1.S.

22. Latvijas Republikas Augstākās tiesas Civillietu departamenta 2018. gada 27. jūnija spriedums lietā Nr. SKC-5/2018 (C39102313). ECLI:LV:AT:2018:0627.C39102313.1.S.

23. Latvijas Republikas Augstākās tiesas Civillietu departamenta tiesneša Normunda Salenieka 2018. gada 29. jūnija Atsevišḳās domas lietā Nr. SKC-5/2018 (C39102313) ECLI:LV:AT:2018:0629.C39102313.2.L.

24. Latvijas Republikas Augstākās tiesas Civillietu departamenta tiesnešu Valerijana Jonikāna un L,ubovas Kušnires (attiecībā uz I punktu) 2018. gada 27. jūnija Atsevišḳās domas lietā Nr. SKC-5/2018 (C39102313) ECLI:LV:AT:2018:0629.C39102313.4.L. 
Arta Snipe. Tiesisks darījums un tā noslēgšanas brīdis zemes

likumiskās (piespiedu) nomas tiesisko attiecību gadījumā

25. Augstākās tiesas Senāta Civillietu departamenta 2007. gada 7. novembra spriedums lietā Nr. SKC - 712/2007.

26. Augstākās tiesas Senāta Civillietu departamenta 2009. gada 25. februāra spriedums lietā Nr. SKC-71/2009 (C33186205).

27. Augstākās tiesas Senāta Civillietu departamenta 2010. gada 15. septembra spriedums lietā Nr. SKC-174/2010 (C04355106).

28. Augstākās tiesas Senāta Civillietu departamenta 2011. gada 13. aprīḷa spriedums lietā Nr. SKC-43/2011.

29. Kurzemes apgabaltiesas Civillietu tiesas kolēgijas 2017. gada 19. decembra spriedums lietā Nr. C30471317. ECLI:LV:KUAT:2017:1219.C30471317.6.S.

30. Kurzemes apgabaltiesas Civillietu tiesas kolēgijas 2017. gada 8. augusta lēmums lietā Nr. C30636016.

31. Latgales apgabaltiesas Civillietu tiesu kolēgijas 2017. gada 18. septembra spriedums lietā Nr. C29403716. ECLI:LV:LAAT2017:0918.C29403716.1.S.

32. Rīgas apgabaltiesas Civillietu tiesas kolēgijas 2017. gada 11. oktobra spriedums lietā Nr. C30454917. ECLI:LV:RAT:2017:1011.C30454917.2.S.

33. Rīgas apgabaltiesas Civillietu tiesu kolēgijas 2017. gada 13. februāra spriedums lietā Nr. C30673715.

34. Rìgas pilsētas Vidzemes priekšpilsētas tiesas 2018. gada 3. maija spriedums lietā Nr. C32195817. ECLI:LV:RVPT:2018:0503.C32195817.3.S.

35. Satversmes tiesas 2009. gada 13. februāra spriedums lietā Nr. 2008-34-01/ Latvijas Vēstnesis. 27 (4013). 18.02.2009.

36. Satversmes tiesas 2011. gada 25. oktobra spriedums lietā Nr. 2011-01-01/ Latvijas Vēstnesis. 171 (4569). 28.10.2011.

37. Vidzemes rajona tiesas 2018. gada 23. aprīḷa spriedums lietā Nr. C33461617. ECLI:LV:VRT:2018:0423.C33461617.4.S.

38. Zemgales apgabaltiesas 2016. gada 21. aprīḷa lēmums, lietas arhīva Nr. CA-0235-16/13.

39. Zemgales apgabaltiesas 2016. gada 4. aprīḷa lēmums lietā Nr. 3-11/0057.

\section{Literatūra}

40. Kārkliṇš, J. 2018. Noilgums piespiedu nomas attiecībās komerctiesībās. Jurista Vārds. 9 (1015), 14-19.

41. Neimanis, J. 2004. Ievads tiesībās. Rīga: Zv. adv. Jānis Neimanis.

42. Rozenfelds, J. 2000. Lietu tiesības. Rīga: Zvaigzne ABC.

43. Sinnott-Armstrong, W., Fogelin, R. 2015. Understanding Arguments: An introduction to Informal Logic. $9^{\text {th }}$ ed. Stamford: Cengage Learning.

44. Snipe, A. 2018. Par saistības un prasības noilgumu saistībai, kas radusies uz likuma pamata. Jurista Värds. 40(994), 23-25.

45. Snipe, A. 2018. Satversmes tiesas konsekventā cīṇa ar Saeimas populismu. Jurista Vārds. 23(1029), 22-29.

46. Torgāns, K. 2014. Saistību tiesības. Rīga: Tiesu namu aǵentūra.

47. Torgāns, K. zin. red. 2006. Civilprocesa likuma komentāri. Trešais papildinātais izdevums. Rīga: Tiesu namu ağentūra.

48. Vīnzarājs, N. 2000. Civiltiesību problēmas. Raksti (1932.-1939.). Rīga: E. Kalniṇa un V. Tihonova izdevums. 
Arta Snipe. Tiesisks darījums un tā noslēgšanas brīdis zemes

likumiskās (piespiedu) nomas tiesisko attiecību gadījumā

\section{Interneta resursi}

49. Bērtule, A. 21.07.2017. Ieilgušas tiesvedības dēḷ no 700 dzīvokḷu īpašniekiem grib piedzìt parādu par zemes nomu. LSM.lv. Iegūts no: https://www.lsm.lv/raksts/zinas/latvija/ieilgusastiesvedibas-del-no-700-dzivoklu-ipasniekiem-grib-piedzit-paradu-par-zemes-nomu.a220157/ [sk. 13.06.2018.].

50. Latvijas Republikas tiesībsargs. 26.08.2010. Par atzinumu pārbaudes lietā Nr. 6-6/236. Nav publicēts. Iegūts no: https://ej.uz/CPL77 [sk. 13.06.2018.].

51. LETA. 27.02.2017. Daudzdzīvokḷu namu īpašniekiem prasa samaksāt 10 gadus vecu nomas maksas parādu par zemi. LETA. Iegūts no: http://www.tvnet.lv/financenet/finansu_zinas/649269-daudzdzivoklu_namu_ipasniekiem_prasa_samaksat_10_gadus_vecu_nomas_maksas_paradu_par_ zemi [sk. 13.06.2018.].

52. LR Tieslietu ministrija. 21.03.2017. Piespiedu nomas tiesisko attiecību aktuālie jautājumi. LR Tieslietu ministrijas informācija presei. Iegūts no: https://www.tm.gov.lv/lv/aktualitates/tminformacija-presei/piespiedu-nomas-tiesisko-attiecibu-aktualie-jautajumi-2 [sk. 15.05.2018.].

53. Patērētāju tiesību aizsardzības centrs. 2017. Informācija patērētājiem par SIA "Vienotais norēḳinu centrs" un AS "Pilsētas zemes dienests" darbību, pieprasot zemes nomas parādus. Patērētāju tiesību aizsardzības centra informācija patērētājiem. Iegūts no: http://ptac.gov.lv/lv/news/informacija-pateretajiem-par-sia-vienotais-norekinu-centrs-un-pilsetas-zemes-dienests-darbibu [sk. 13.06.2018.].

54. Valsts ieṇēmumu dienests. 01.08.2014. Par uzziṇas sniegšanu, Nr. 8.11-20/63149. VID uzziṇas, vēstules. Iegūts no: https://www.vid.gov.lv/lv/vid-uzzinas-vestules [sk. 13.06.2018.]. 